\title{
Study the demand for contraceptive methods in women referring to Health Centers in Qazvin, Iran (2017)
}

\author{
$\underline{\text { Sh. Khourani }}^{1}$, S. Asefzadeh ${ }^{2}$, H. Dargahi ${ }^{3}$
}

\begin{abstract}
${ }^{1}$ Department of Health Services Management E-Campus, Islamic Azad University, Tehran, Iran
${ }^{2}$ School of Health, Qazvin University of Medical Sciences, Qazvin, Iran

${ }^{3}$ Department of Health Care Management, School of Health, Health Information Management Research Center, Tehran University of Medical Sciences, Tehran, Iran

Corresponding Address: Shabnam Khourani, Department of Health Services Management E-Campus, Islamic Azad University, Tehran, Iran

Tel: +98-912-7891697, Email: shabnamkhorani@yahoo.com

Received: 15 May 2018; Accepted: 15Sep 2018
\end{abstract}

*bstract

Background: Family planning means planning for the future of fertility and is aimed at preventing unplanned and high-risk pregnancies, illicit abortions and providing maternal and child health.

Objective: The present study evaluated the demand for contraceptive methods in women referring to health centers in Qazvin, Iran in 2017.

Methods: This descriptive-analytical study was conducted in 11comprehensive centers of urban health services in Qazvin. The research population were 384 married women from 10-49 years old who referred to the health centers by simple random sampling method Data collection tools were done by researcher-made questionnaire, interview and reviewing family profiles. Data were analyzed using $\mathrm{X}^{2}$ and Spearman correlation coefficient.

Findings: The mean age of women was $31.79 \pm 6.376$ years. Among families, $40.6 \%$ had only one child and $57.8 \%$ of them didn't want to have a child in the future. Also, 51\% of them used natural distancing method and $16.4 \%$ used condom as a contraceptive device and didn't have any plan to use confident methods. There was a significant relationship between age, education, receiving useful trainings and consulting services with the current distancing method $(\mathrm{P}<0.05)$.

Conclusion: According to the results, the difference between the use and demand for distancing devices may lead to increase unwanted pregnancy and abortion. Therefore, interventions need to adjust the age of marriage, develop free services for distancing methods, and promote the management of educational and consulting services for families who are not interested in childbearing.

Keywords: Family planning, Contraceptive methods, Pregnancy, Induced abortion, Urban health services

Citation: Khourani SH, Asefzadeh S, Dargahi H. Study the demand for contraceptive methods in women referring to Health Centers in Qazvin, Iran (2017). J Qazvin Univ Med Sci 2018; 22(4): 4050. 


\section{برر سى ميزان استفاده از روشهاى يبشَّيرى از حاملكى در زنان مراجعه كننده به مراكز بهداشتى درمانى شهر قزوين (1) (1)}

شبنم خورانى '، دكتر سعيد آصفزاده'، دكتر حسين درَّاهى

'واحد الكترونيكى كروه مديريت خدمات بهداشتى و درمانى دانشعاه آزاد اسلامى تهران، تهران، ايران

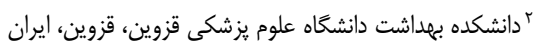

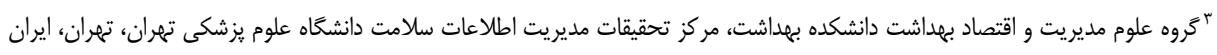
آدرس نويسنده مسئول: تهران، دانشكاه آزاد اسلامى، واحد الكترونيكى، كروه مديريت خدمات بهداشتى و درمانى، تلفن

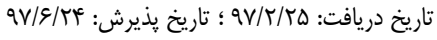

زمينه: تنظيم خانواده به معناى برنامهريزى براى آينده بارورى است و با هدف يِيشَيرى از حاملكى بدون برنامه و يُرخطر، سقطهـاى غيرقانونى و

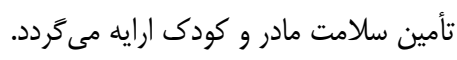

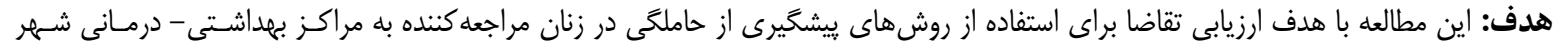
قزوين انجام شد.

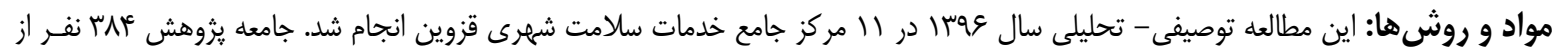

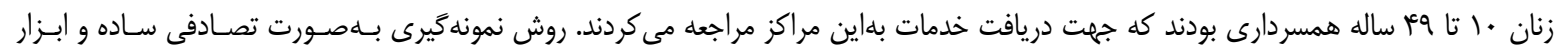

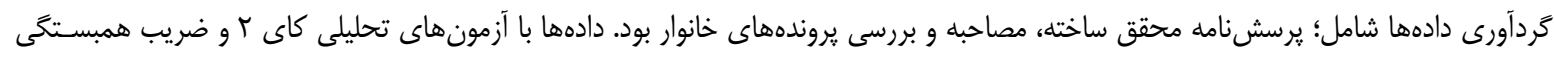
اسوקيرمن تحليل شد.

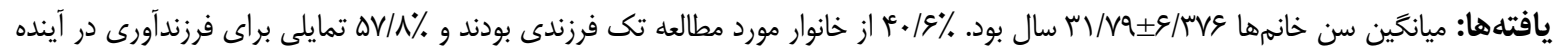

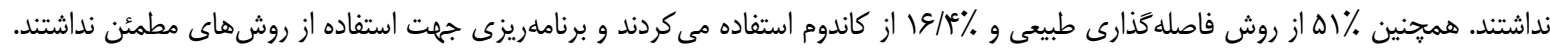

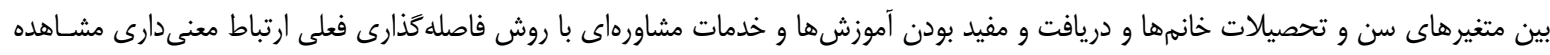
شد (ه) نتيجهَّيرى: طبق نتايج در خانمهاى مورد مطالعه، تفاوت ميان استفاده و تقاضا براى وسايل فاصله كذارى، احتمال دارد حـاملكى هـاى ناخواسـته و

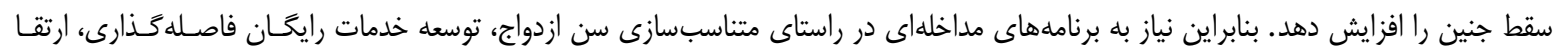

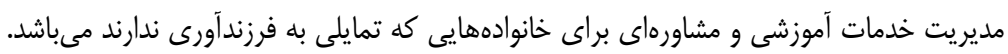

كليدوازهها: تنظيم خانواده، روشهاى ييشَّيرى از باردارى، باردارى، سقط جنين، مراكز جامع سلامت

مقدمه:

كاملى از روش هاى مؤثر و مطمئن جلـو گيرى از بـاردارى

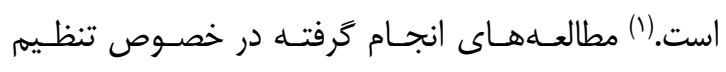
خانواده نشان مىدهد رشد سريع جمعيت در ايران يـس از ماز

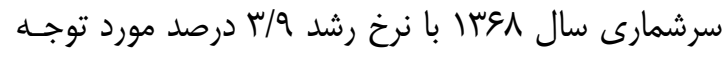

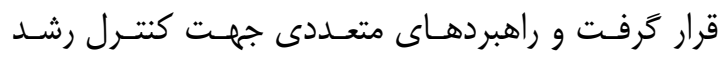
جمعيت در برنامه تنظيم خانواده به عنوان يك اولويست در فر فردير

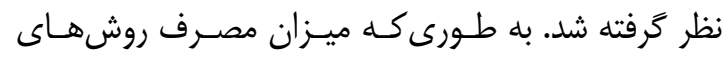

تنظيم خانواده به معناى يِيشخيرى از حاملكى يُرخطر،

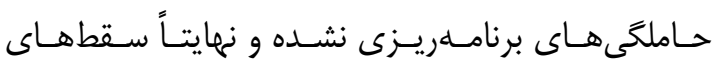

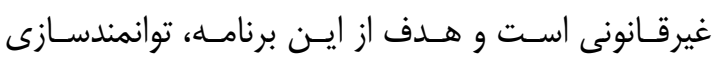

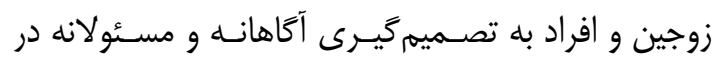
مورد تعداد و فاصله كذارى بين فرزندانشان، برخــوردارى از

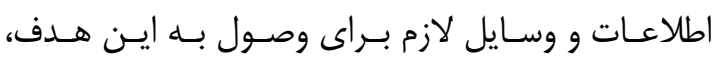

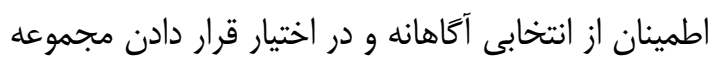


بروز باردارىهاى ناخواسته تا حدود زيادى در ارتبـاط

با رفتارهاى نادرست تنظيم خانواده است؛ به طورى كـه بـاــا

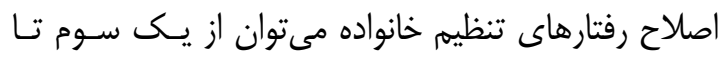

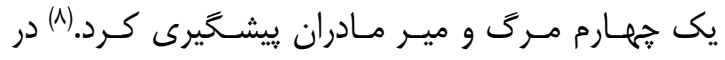
مقابل، موضوع مهم ديكر، رشد جمعيت است. بديهى است

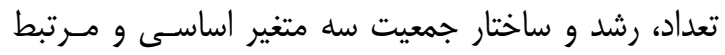

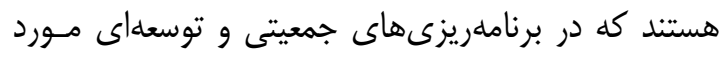

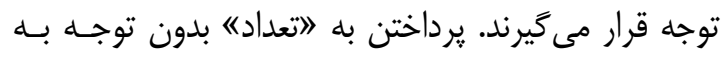

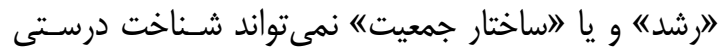

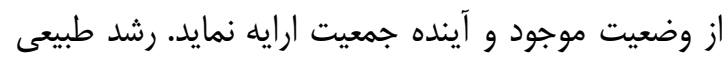

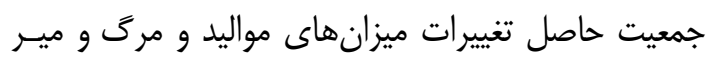

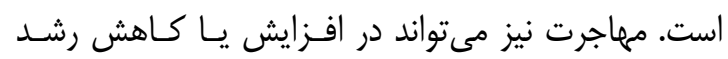

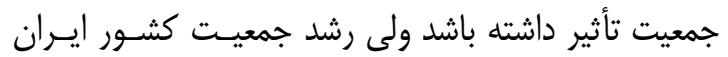

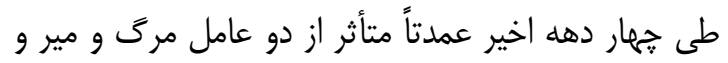

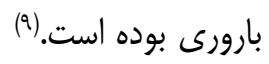
طبق آخرين سرشــارى صـورت كرفتـه در ايـران در

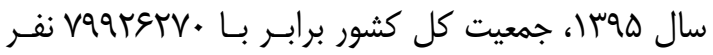

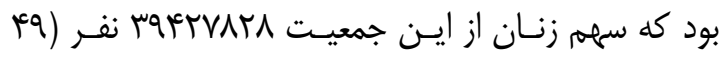

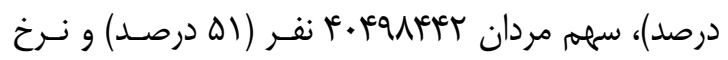

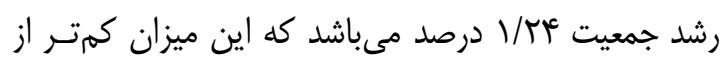

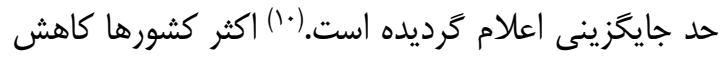

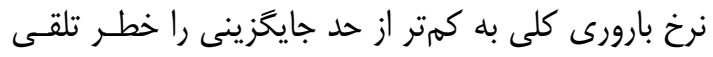
نموده و سياستهاى تشويقى را در مقاطعى از زمان جهت

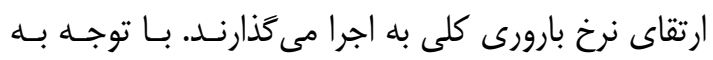

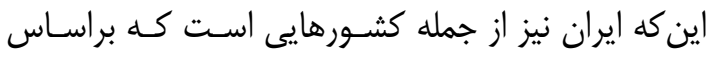

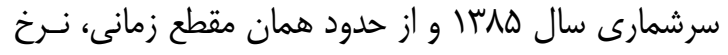

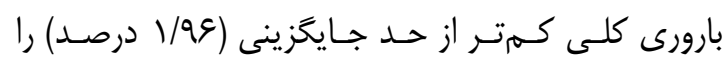

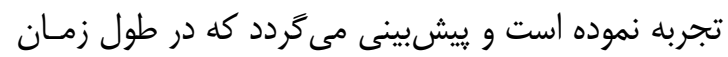

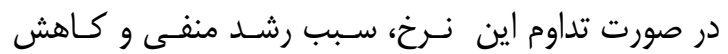

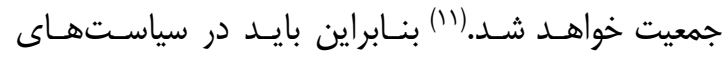

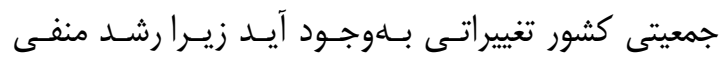

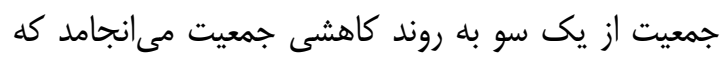

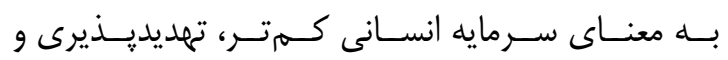

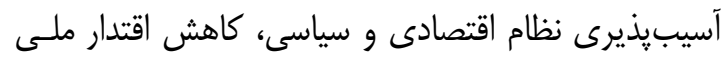

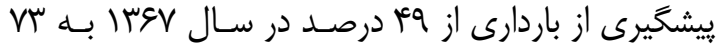

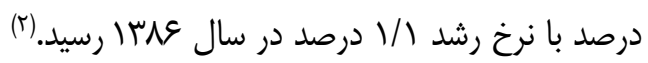

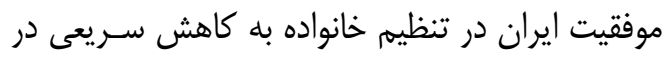

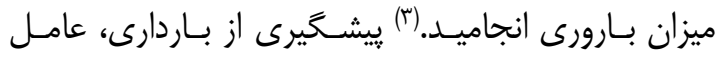

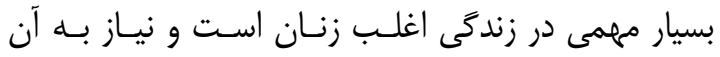

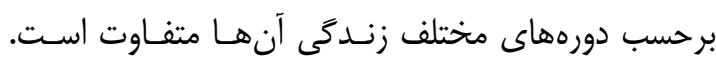

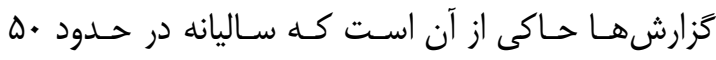

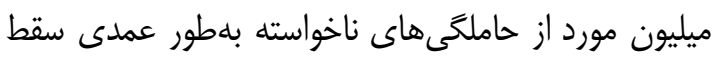

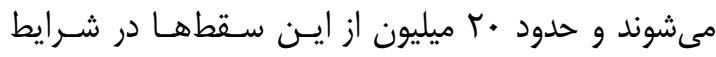

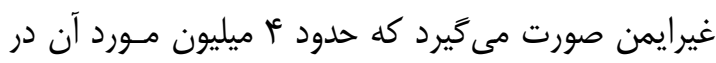

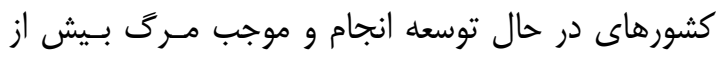

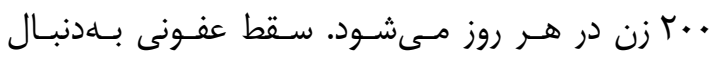

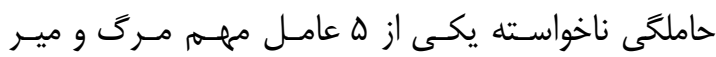
مادران مىباشد. (F) با وجود تلاشهاى روزافزون تنظيم خانواده در ايـران و دسترسى آسان به وسايل ييشگيرى از حاملكَ، سـالانه

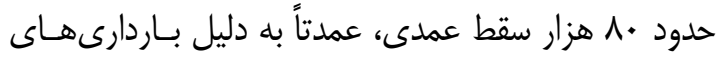

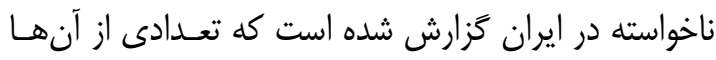

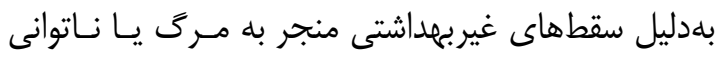

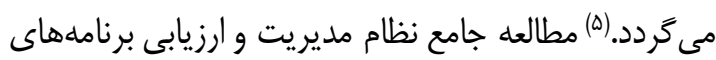
سلامت خانواده كه در سال عربسا در كشـور انجـام شـد،

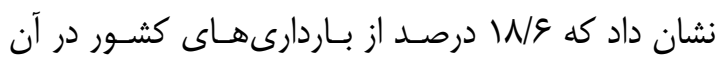

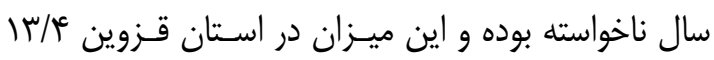

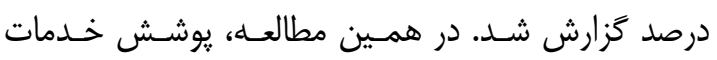

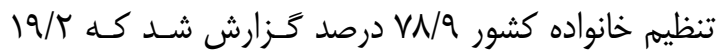

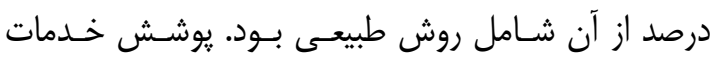

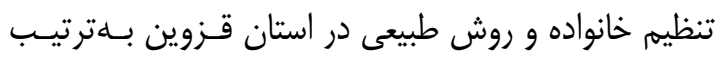

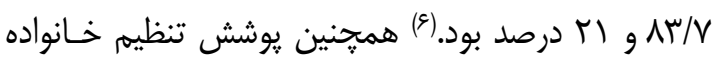
در مناطق شهرى شهرستان البرز (استان قزوين) در سـال

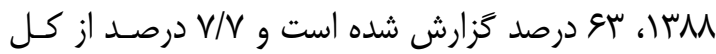

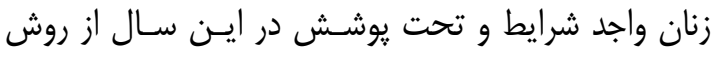

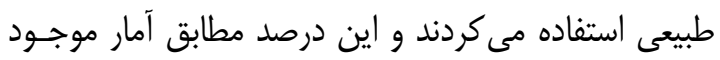

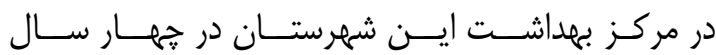
كذشتـه رو بــه افزايش بوده است. (V) 
فرمول كوكران ז

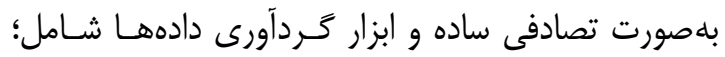

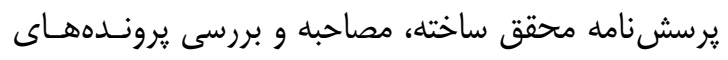

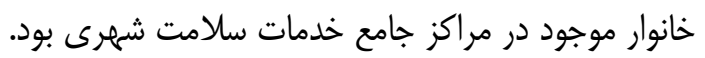

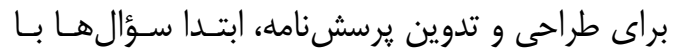

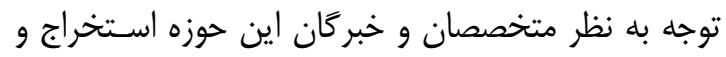

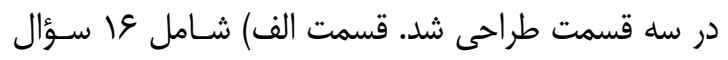
در خصوص مشخصات فردى زنان خانوار و همسرانشـان، ب) شامل سب سؤال در خصوص خدمات فردات سلامت بـارورى

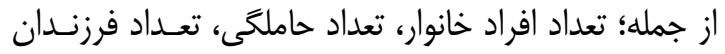

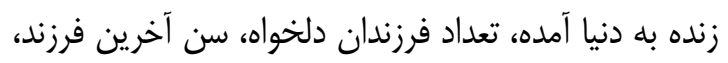

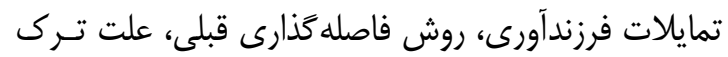

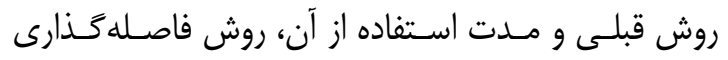

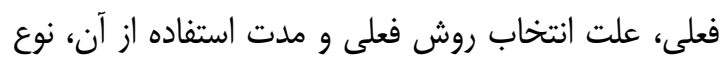

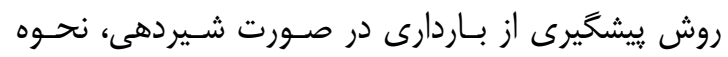

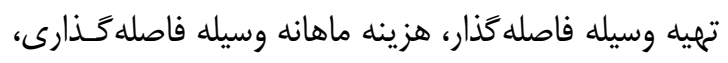

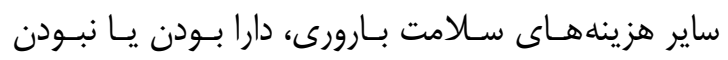

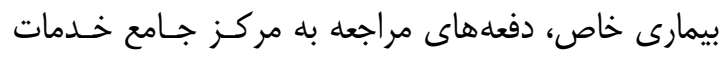

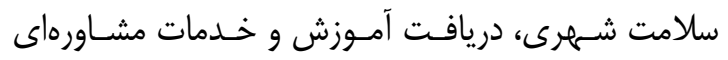

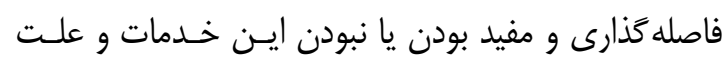

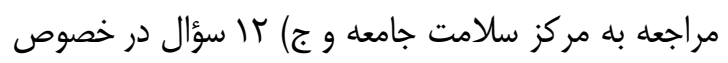

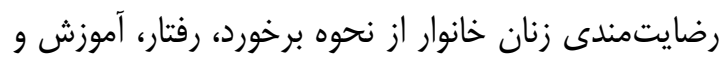

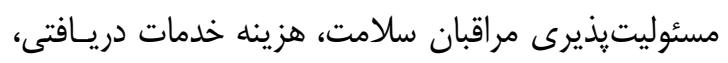
ارايه خدمات موجود در مركز سلامت، خدمات مورد انتظار

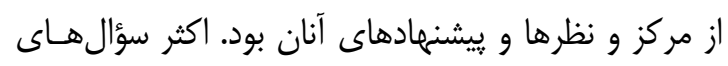

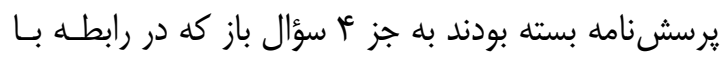

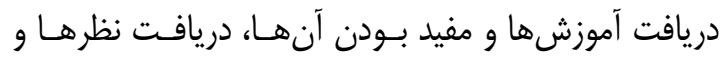

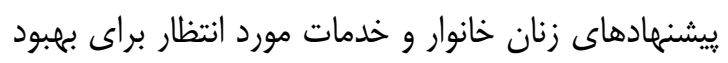

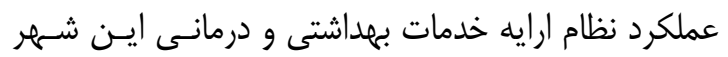

براى تعيين روايى محتوايى از دو روش كيفى و كمى

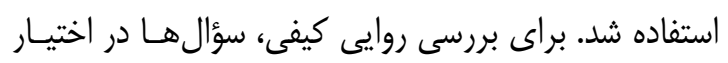

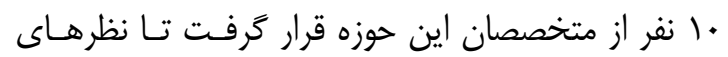

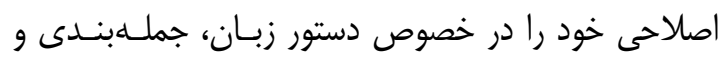

و كاهش احتمالى نقش كشورها در رقابتهاى بينالمللى

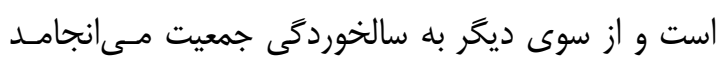

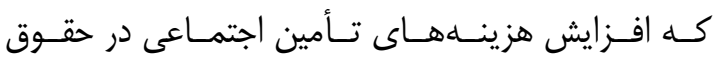

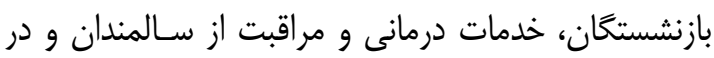
نهايت ركود اقتصادى رادر يـى دارد.

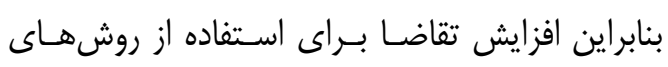

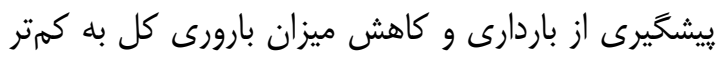

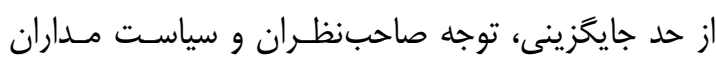

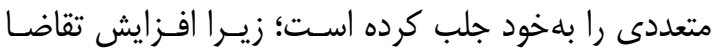

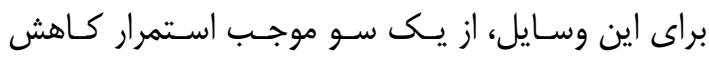

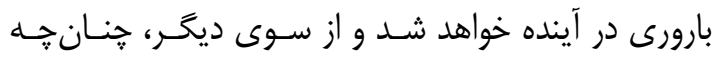

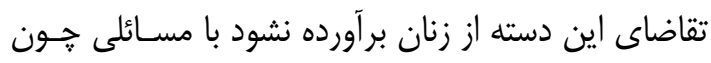

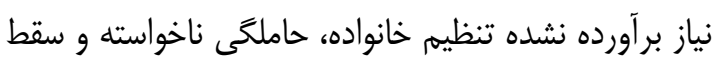

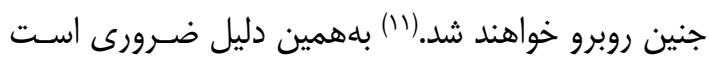

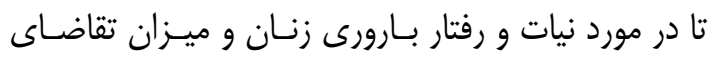

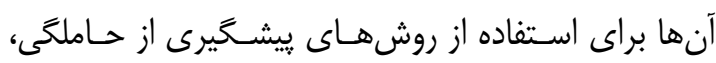

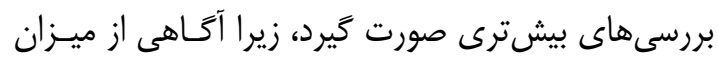

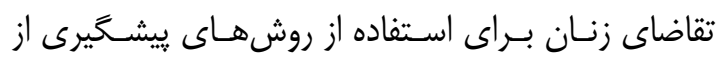

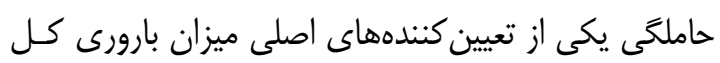

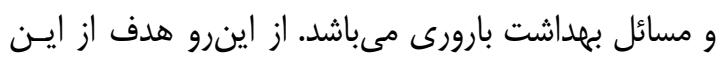

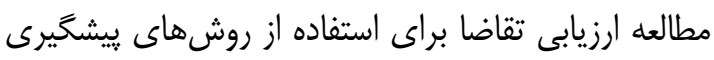

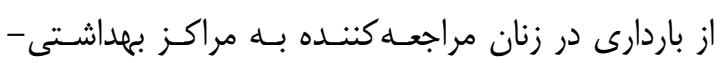
درمانى شهر قزوين در سال عهسا مى باشد.

\section{مواد و روشها:}

اين مطالعه توصيفى - تحليلى در سال عوسا در مراكز

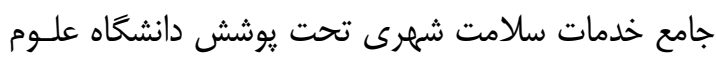

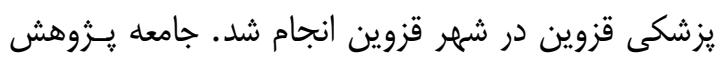

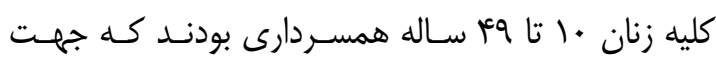

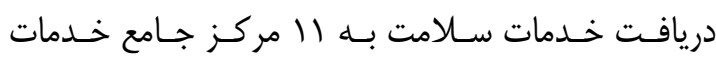
سلامت شهرى موجود در شهر قزوين مراجعه مسى كردنــــ

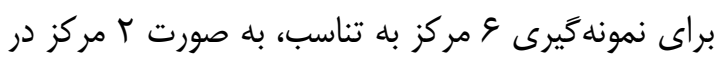

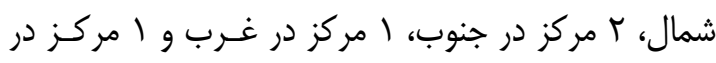

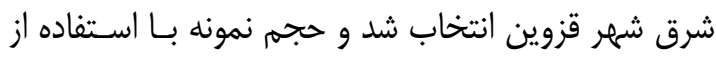




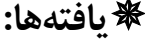

بيشترين توزيع فراوانى سـن زنـان خـانوار در كَروه

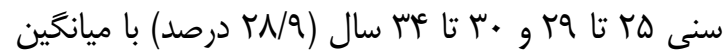

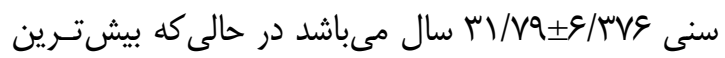

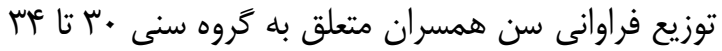

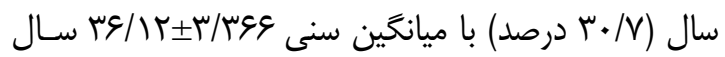

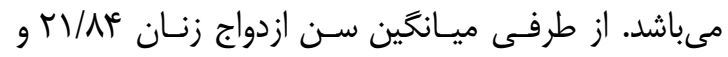

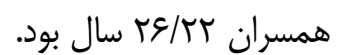

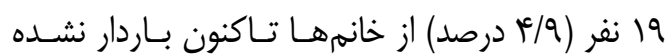

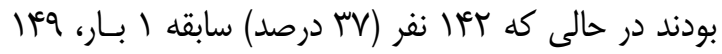

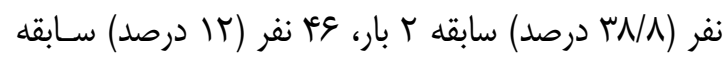

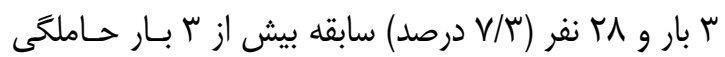

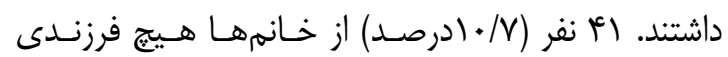

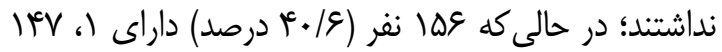

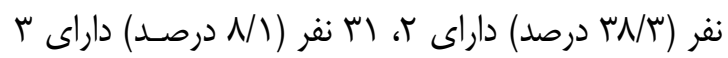

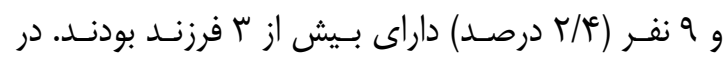

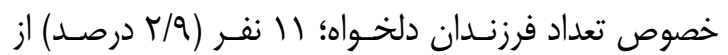

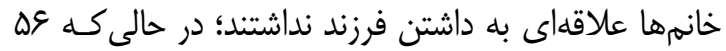

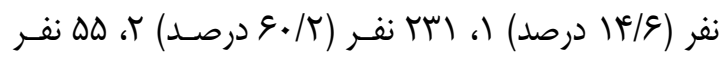

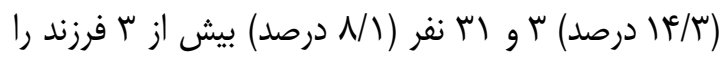

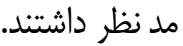

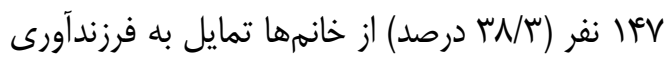

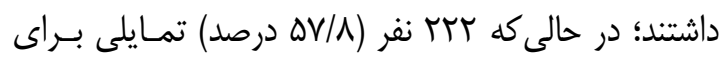

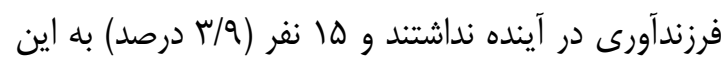

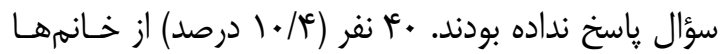

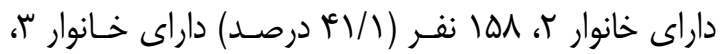

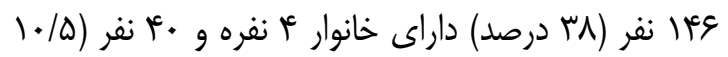

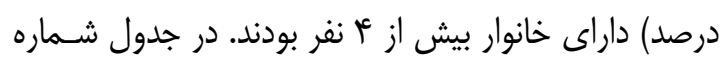
يك به رايجترين وسايل فاصله كذارى مورد استفاده خانوار

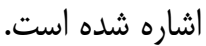
وVا نفر (ه/هـ درصد) از خانمها علت انتخـاب روش

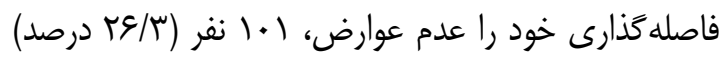

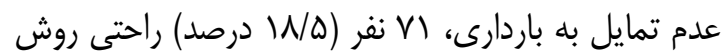
و أ نفر (ا درصد) عدم حساسيت به روش عنوان نمودنــ؛
قـرار گــرفتن عبـارات در جـاى مناسـب اعـلام نماينــد و

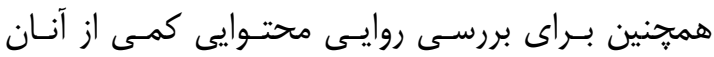

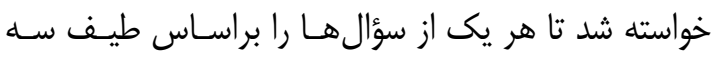
بخشى ليكرت اضرورى است)، امفيد است ولى ضرورى

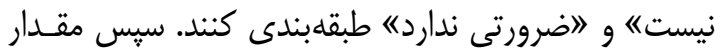

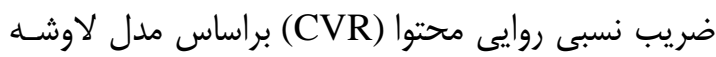

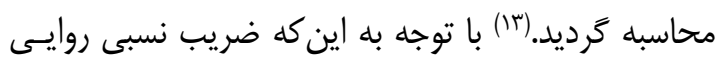

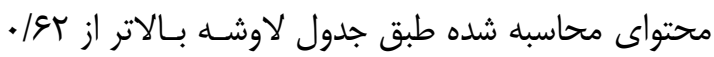

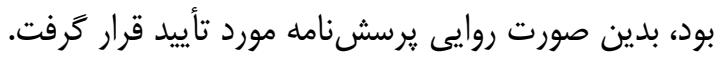

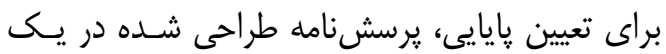

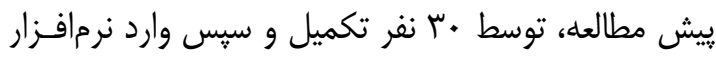

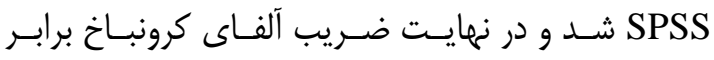
A9QT • بهدست آمد كـه جـون ضـريب آلفـاى كرونبـاخ

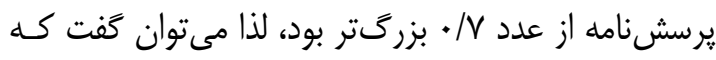

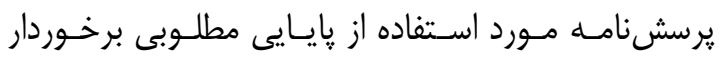

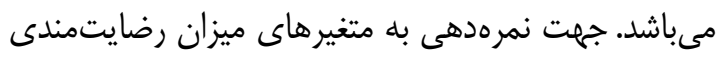

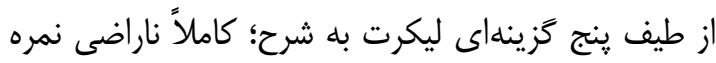

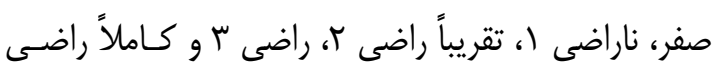

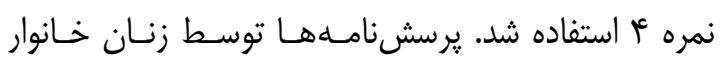

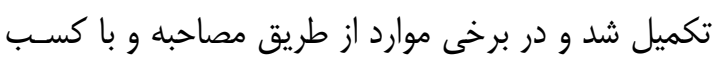

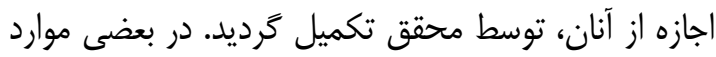

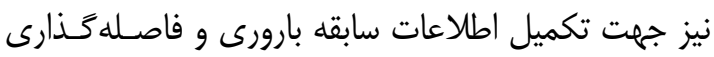
آنها از اطلاعات موجود در يروندههاى خانوار استفاده شد.

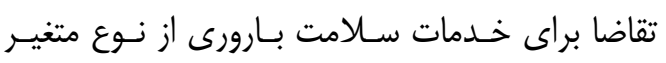

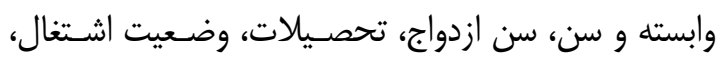

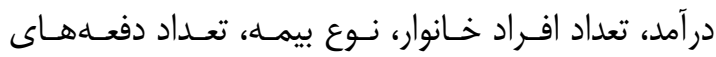

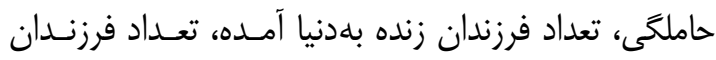

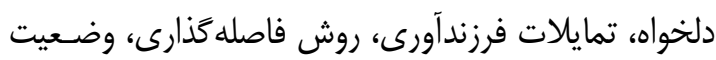
شيردهى، نحوه تهييه وسيله فاصله كذارى و هزينـه ماهانـهـ

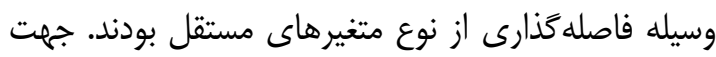

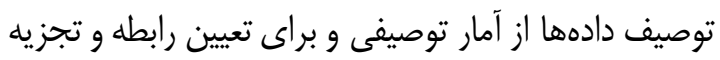

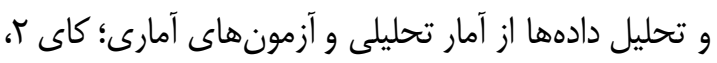

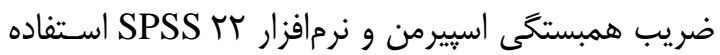

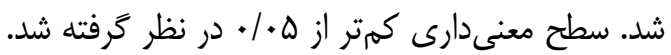


داد (ه•/ (P<). در حالى كه يافتهها حـاكى از آن بـود كـهـ

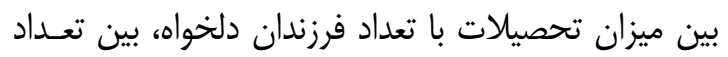

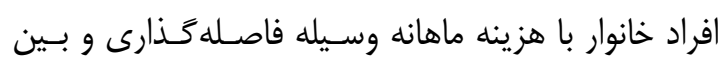

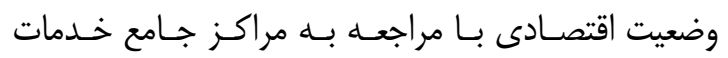
سلامت شهرى رابطه معنادارى وجود نداشـت (ه + • (P>).

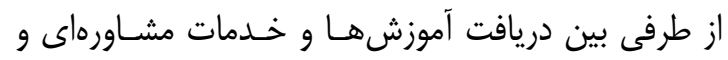

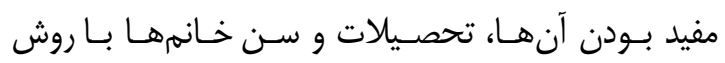

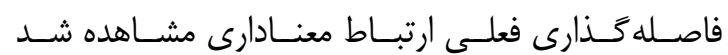

.$(\mathrm{P}<\cdot / \cdot 0)$

\section{جدول ا - توزيع فراوانى روشهاى بيشگيرى از باردارى}

\begin{tabular}{|c|c|c|}
\hline درصد & فراوانى & روش فاصلهَذارى \\
\hline$N / 1$ & r) & قرص \\
\hline $18 / 4$ & gr & كاندوم \\
\hline$r / r$ & 19 & أميول \\
\hline$N / 1$ & ו ו & IUD \\
\hline Q) & 198 & طبيعى \\
\hline$\cdot / r$ & 1 & وازكتومى \\
\hline$r / \varphi$ & 15 & توبكتومى \\
\hline$V / r$ & rA & باردارى \\
\hline 1 & r & بدون ياسخ \\
\hline $1 .$. & rAF & جمع كل \\
\hline
\end{tabular}

\section{بحث و نتيجه}

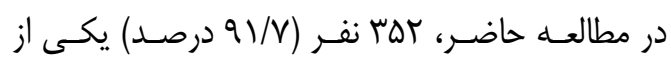

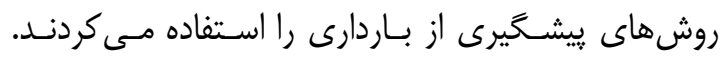

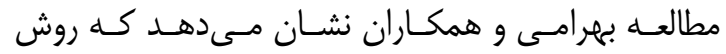

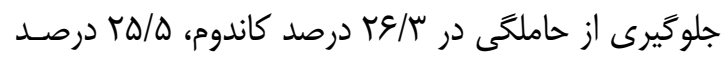

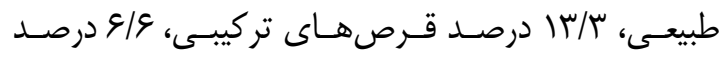

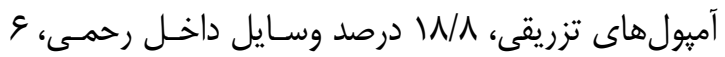
درصد توبكتومى و ع/ץ درصد واز كتومى بود. (IF) بر اين اساس مىتوان كفت اكر اين روند ادامه بيدا كند

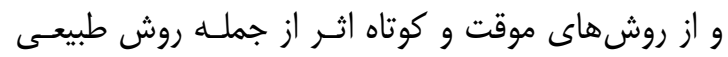

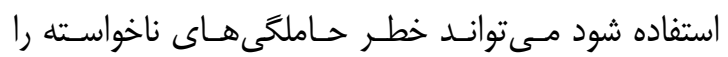
افزايش دهد. مطالعه رهنما و همكاران نيز حـاكى از ايـن

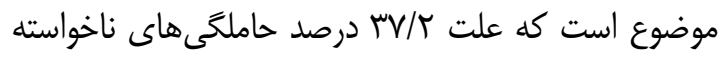

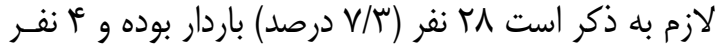

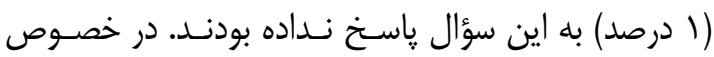

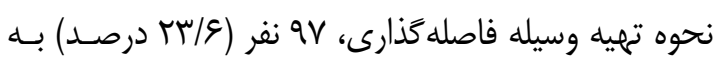

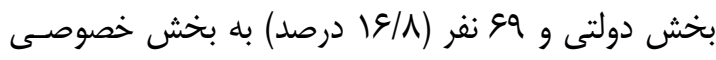
مراجعه كردند. هزينهاى كه خانوار بلهصورت ماهيانه صرف

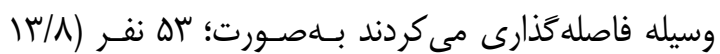

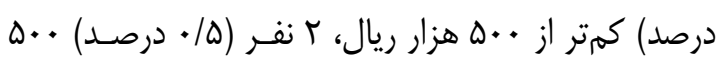

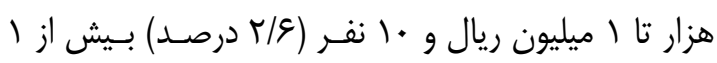

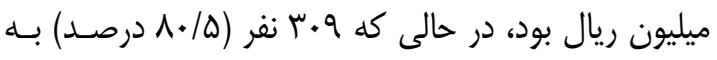

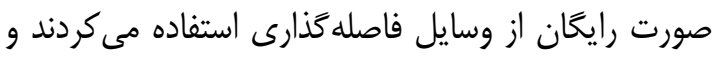

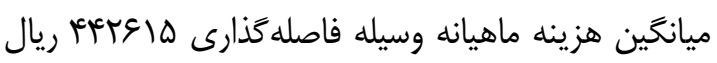

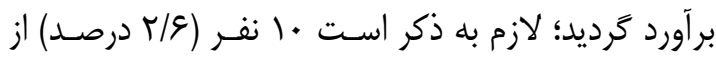
خانمها بعاين سؤال ياسخ نداده بودند.

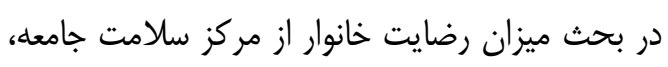

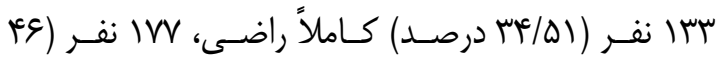

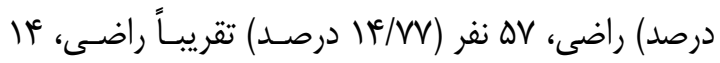

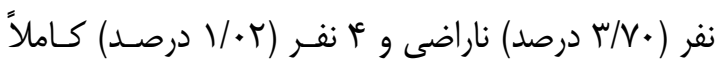
ناراضى بودند. فاهلة

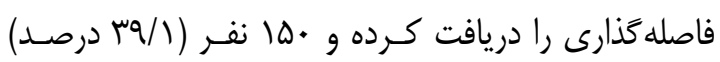

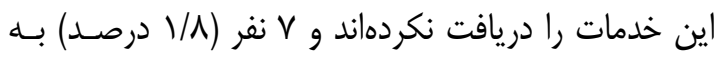

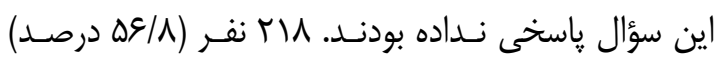

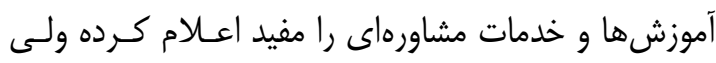

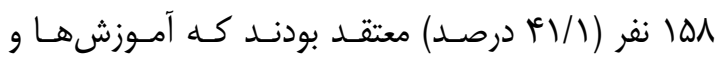

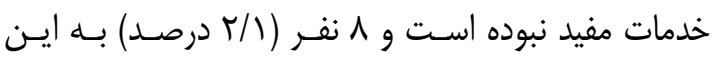
سؤال ياسخ نداده بودند. در تعيين همبستخى و تأثير بين متغيرهاى يزوهش از

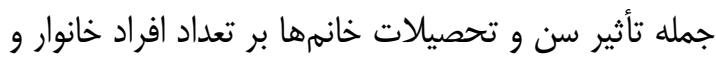

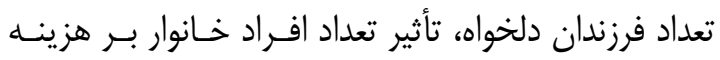

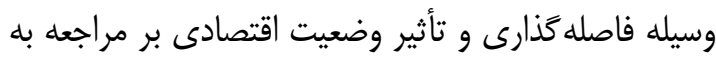

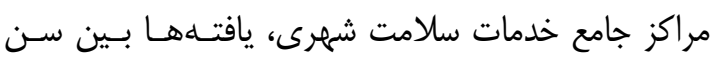

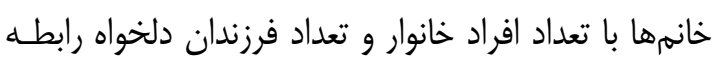

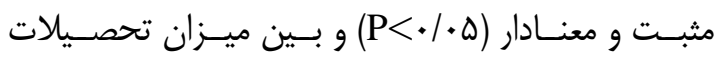

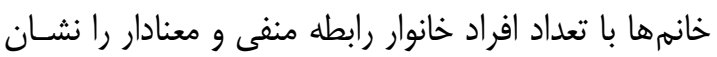


بر اثر حاملحى ناخواسته، استفاده از روشهاى ييشگيرى از

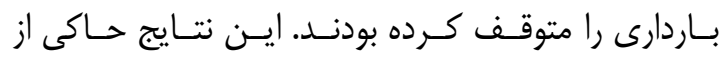

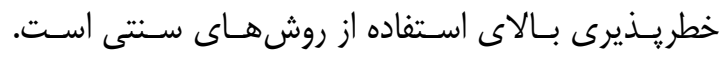

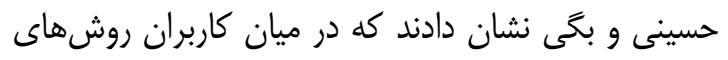

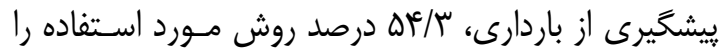

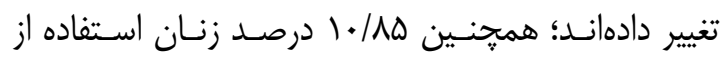

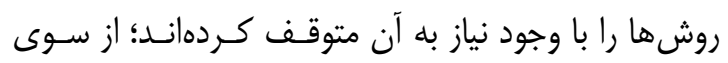

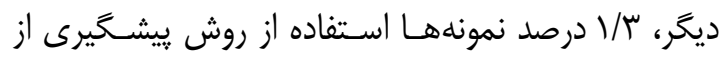

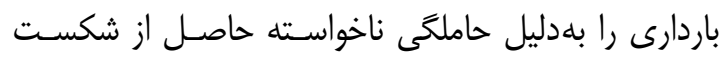

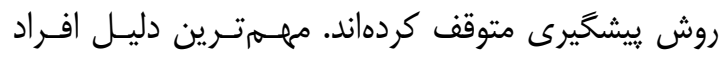

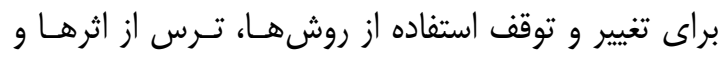
عوارض جانبى روش هاى ييشخَيرى بـوده اسـت و ميـزان

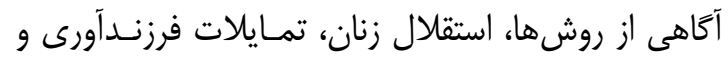

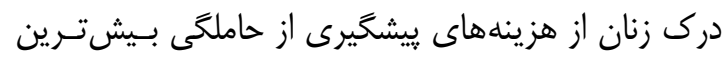

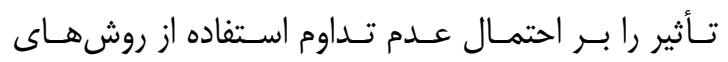
يشخَيرى دارد.

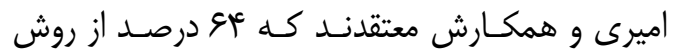

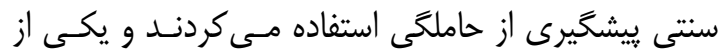

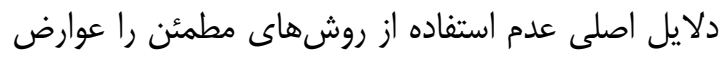

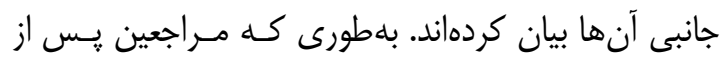

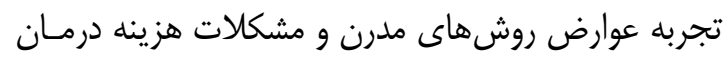

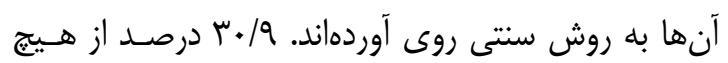

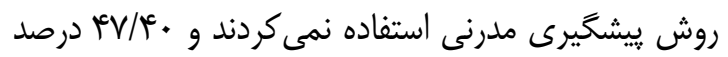

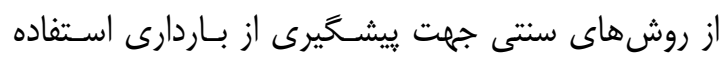

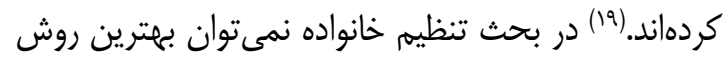
ييشخيرى از باردارى را تعيين كرد، زيرا انتخاب نوع روش تئن

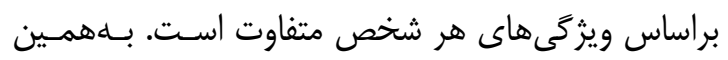

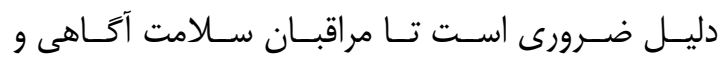
راهنمايىهاى لازم را در ايسن خصـوص بـهـ زنـان خـانوار

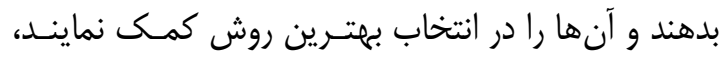
اين امر مستلزم صرف زمان و دادن فرصت كافى به زنـان

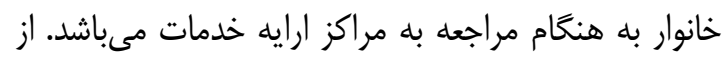

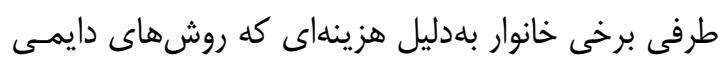

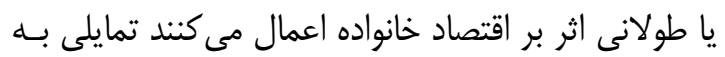

در تهران مربوط به افرادى است كه از نزديكى منقطع بـهـ

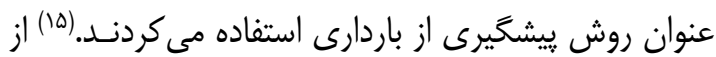

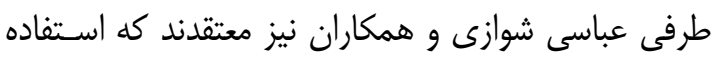

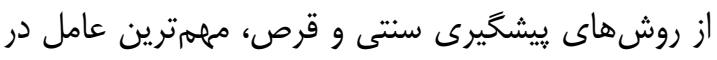

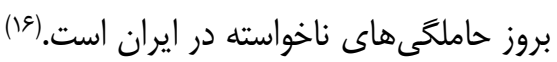

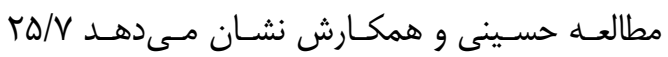

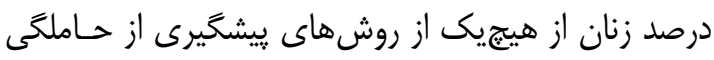

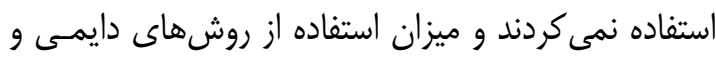

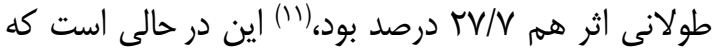

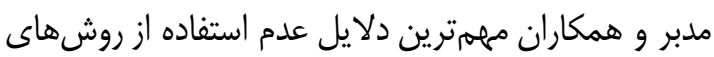

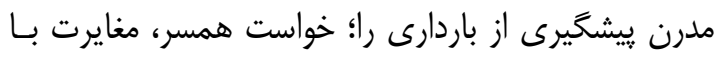

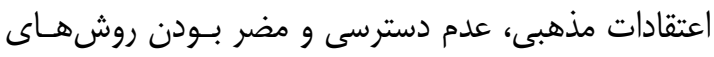

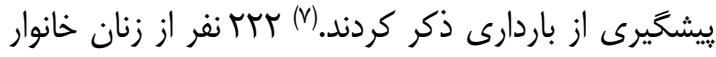
در اين يزوهش تمايلى براى فرزندآورى در آينده نداشتند و آناري

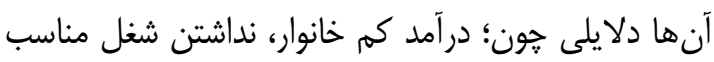

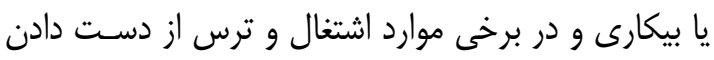

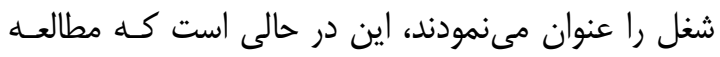

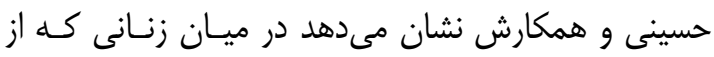

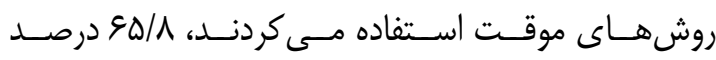

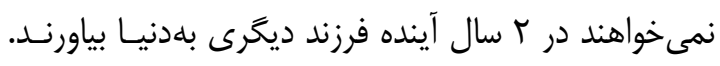
بهاين ترتيب شمار زنانى كه از روشهاى موقت ييشخيرى

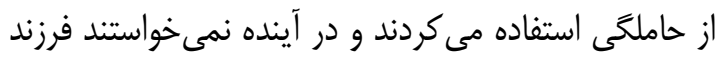

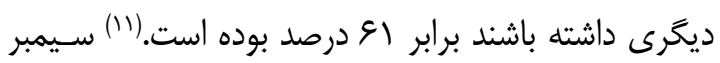

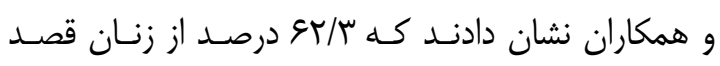

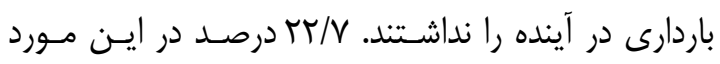

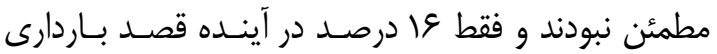
داشتند. (IV)

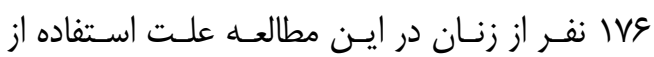

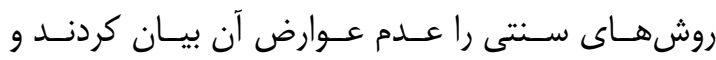
بيشترين تغيير صورت كرفته در روش قرصهاى تركيبى

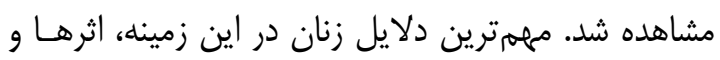
عوارض جانبى مصرف قرصها يا بيمارى بود در حالى كـهـ دئه

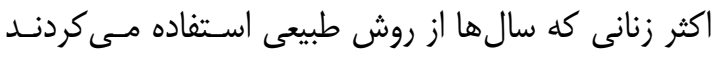

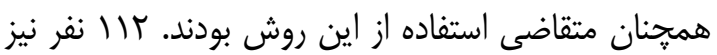


داد كه بين سن زنان با تعداد افراد خانوار و تعداد فرزنــان

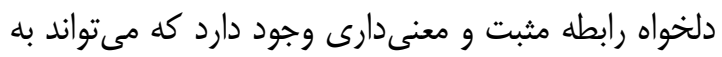

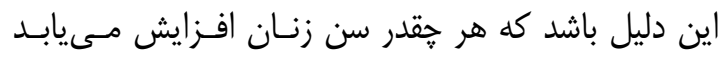

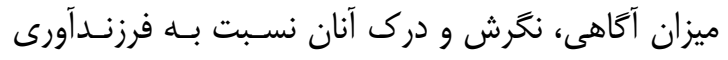

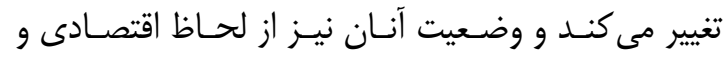

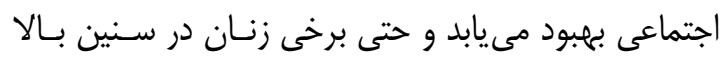

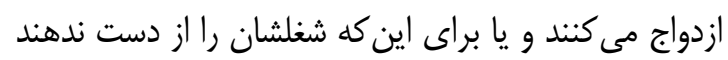

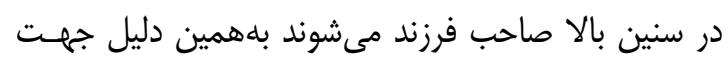
مقابله با از دست رفـتن فرصـت بـارورى تعـداد فرزنــان

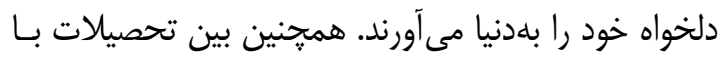

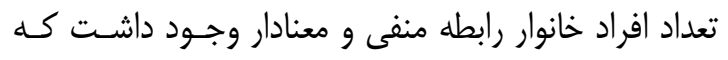
يكى از دلايل آن اين است كه زنان تحصيل كـرده ديرتـر

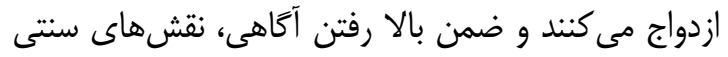

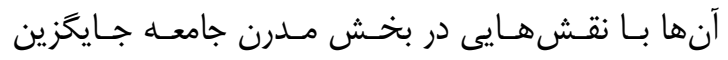

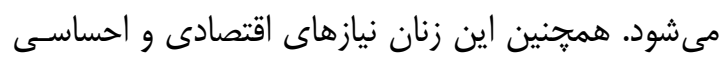

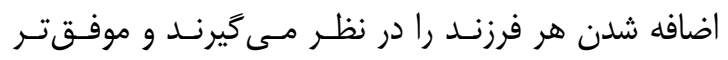

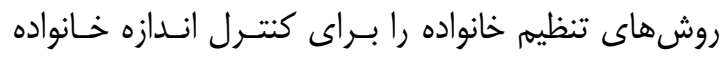

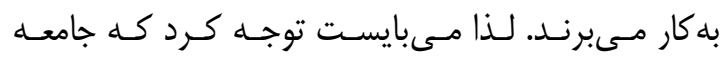

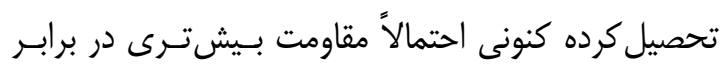

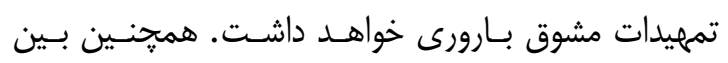

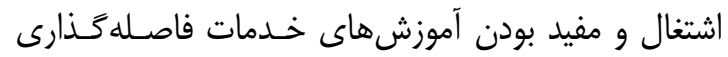
رابطه مثبت و معنادارى وجود دارد.

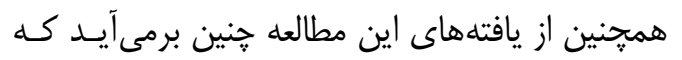

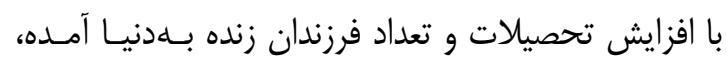

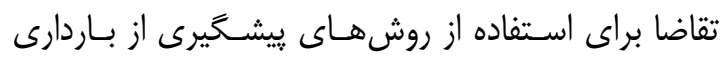

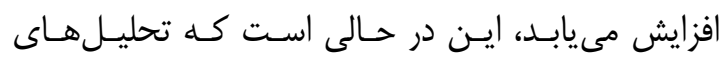

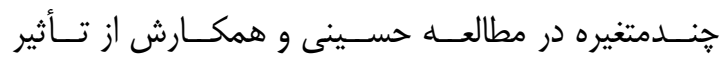

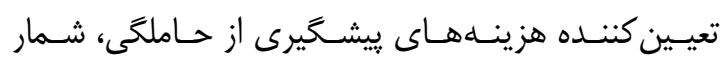

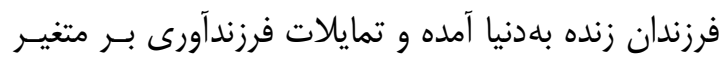

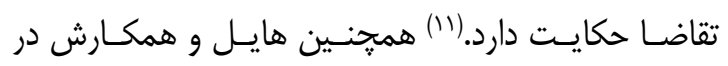

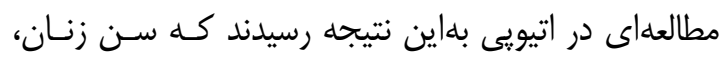

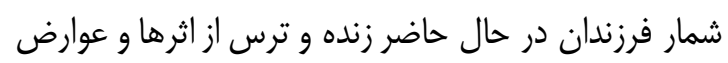

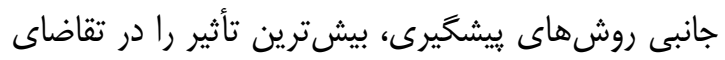

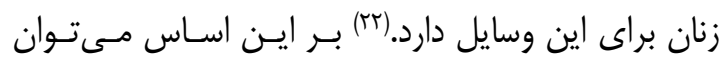

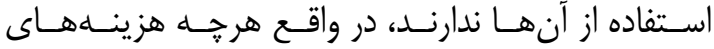

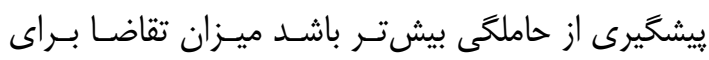

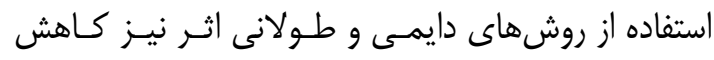

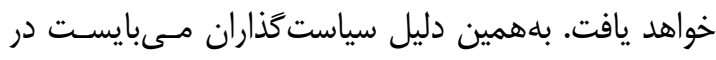
جهت حمايت مادى از خانوارى كه متقاضى استفاده از اين دمان روشها هستند تلاش نمايند.

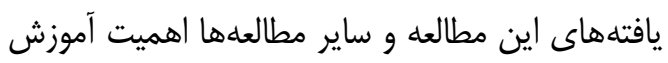
و آكاهى دادن به خانوار را نشان مى دهد. بايد بهاين نكتهـ مائه

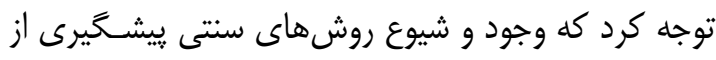

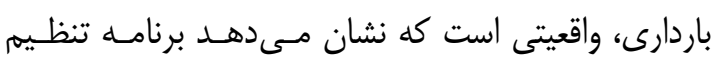

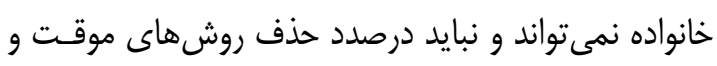

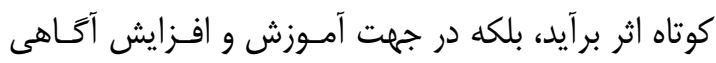
براى كاهش حاملكىهاى ناخواسته ناشى از اين روشهـاء

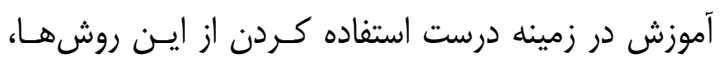

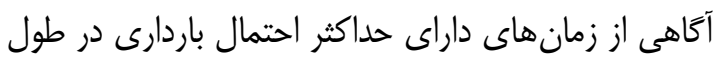

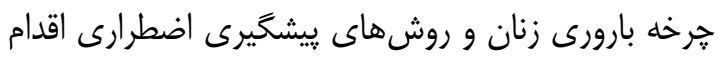

شود.

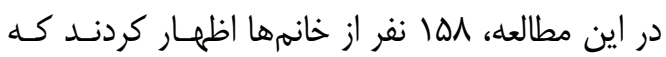

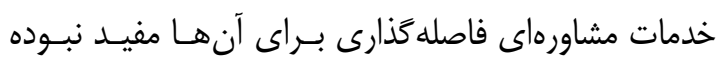

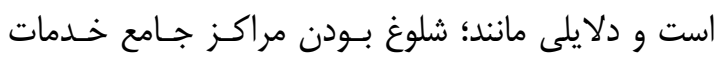

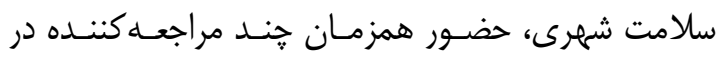

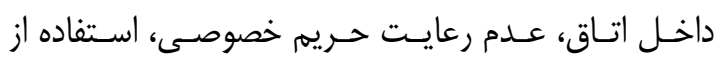

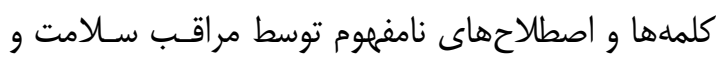

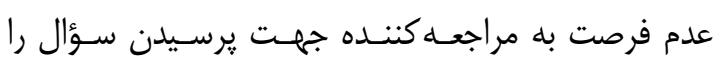

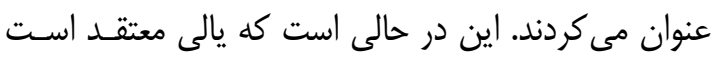

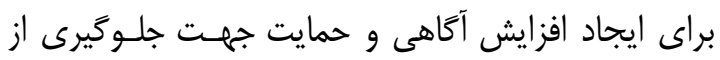

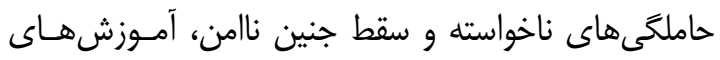

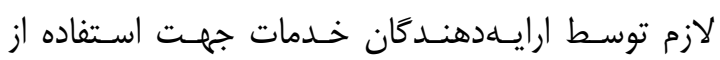

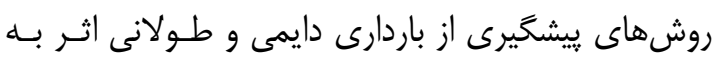

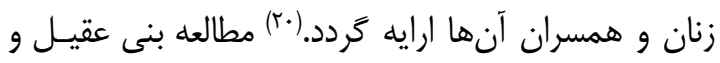

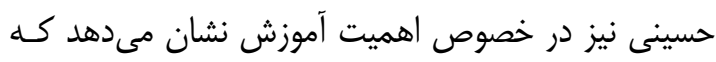

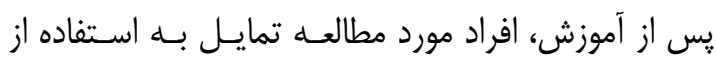
روشهاى مدرن داشتند.(T) از طرفى بررسى رابطه بين متغيرهاى يثوهش نشـان 
تمايل به فرزندآورى ندارند، استفاده از روشهـاى دايمى

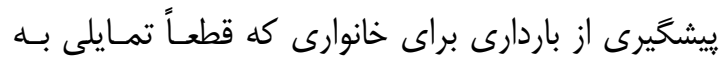

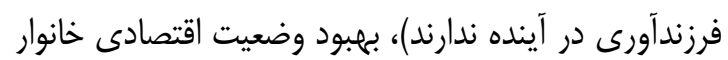

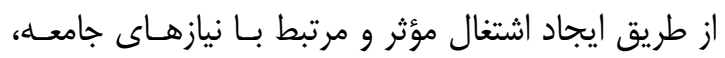

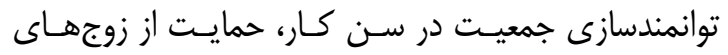

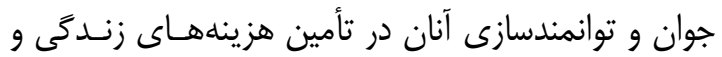

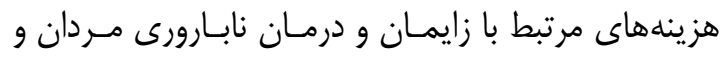

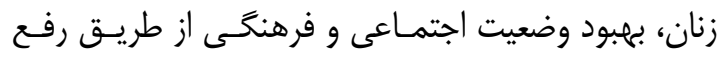

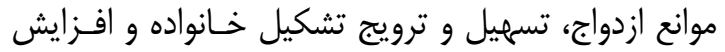

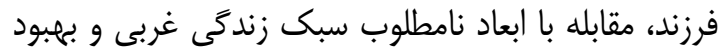

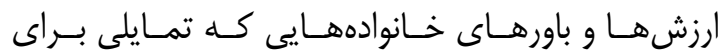
فرزندآَوى ندارند از طريق تحكيم بنيان و يايدارى خانوادها

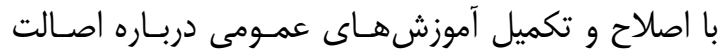

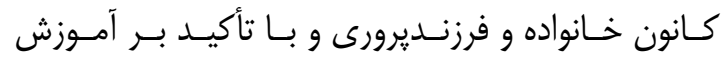

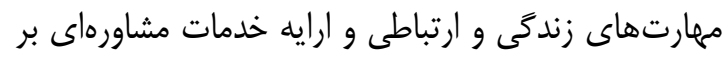

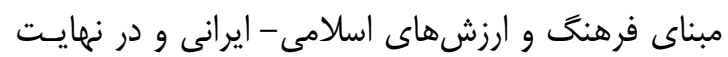

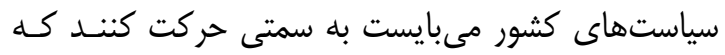

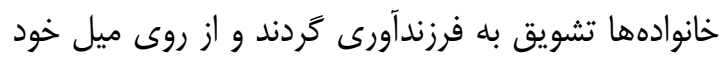

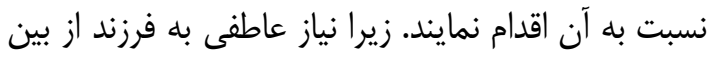

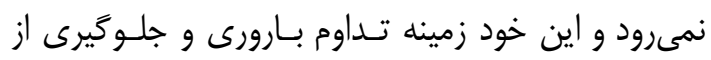
كاهش بيشتر آن است. براى رفع مشكل عـدم تمايـل برخى واحـدها بــراى

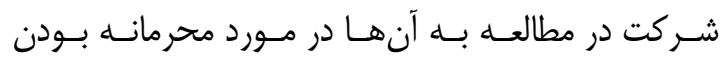

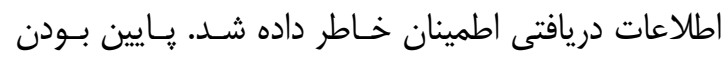

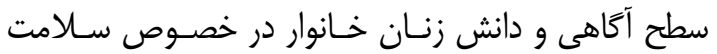
بارورى محدوديتى بود كه ايـن مشـكل بـا صــف زمـان

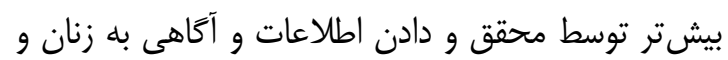
در نهايت توجيه آنان برطرف شد.

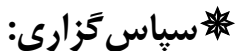

بدينوسيله از همكارى معاونـت تحقيقـات و فنـاورى دانشخاه علوم يزشكى قزوين، معاونت بهداشـتى دانشـاهـاه،

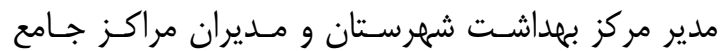
خدمات سلامت شهرى واقع در شهر قـزوين كـه امكـان
كَفت، ميزان تقاضا براى اسـتفاده از وسـايل ييشـخيرى از

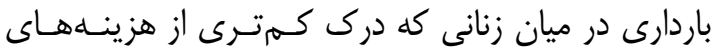

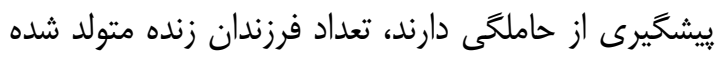

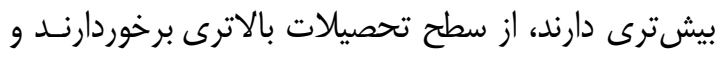
نمى خواهند در آينده فرزند ديخرى داشته باشـند، بـيشتر است. با افزايش هزينـه، ميـزان تقاضـا بـراى اسـتفاده از

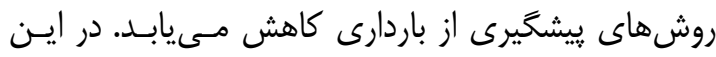

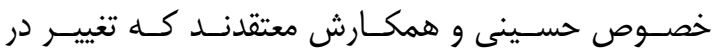
هزينههاى ييشخَيرى از حاملحى در جهت مخالف با متغير

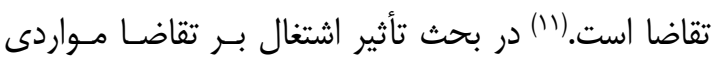

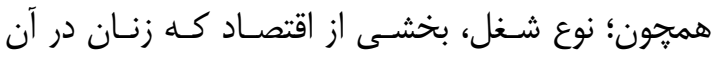

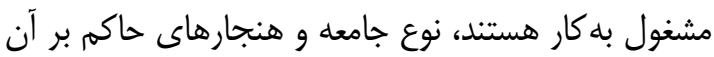

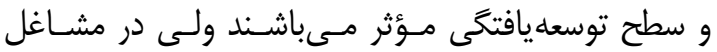

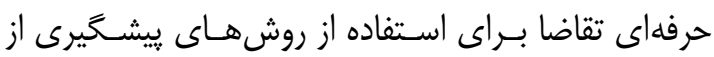
باردارى افزايش مى يابد.

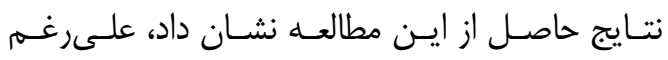

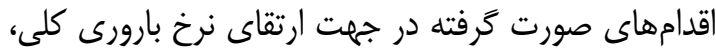

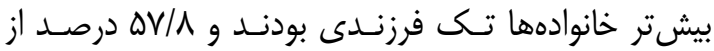

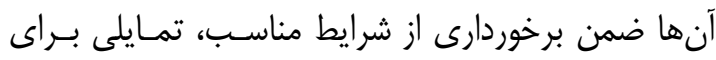

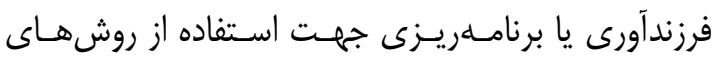
فاصله كذارى طولانى اثر نداشتند. از ايـنرو تفـاوت ميـان

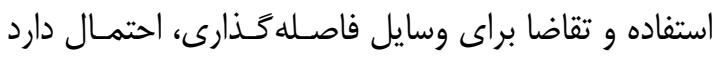

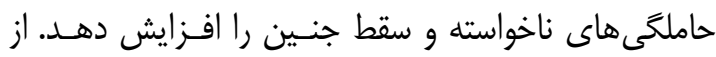

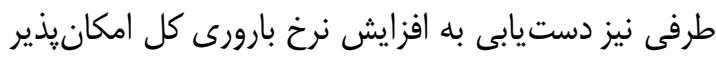

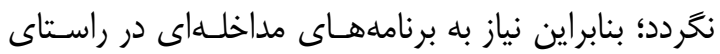
متناسبسازى سن ازدواج (فرهنگسازى كاهش ميـانخين

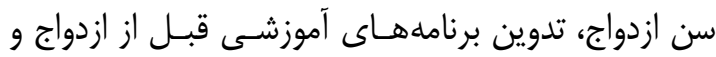

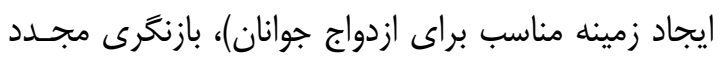
دستور العملهاى سلامت بارورى (توسعه خـدمات رايخـان فاصله كذارى جهت زنان واجد شـرايط)، ارتقـاى مـديريت

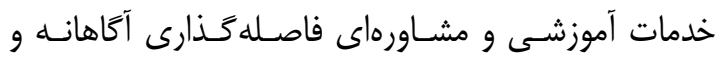
براساس نيازهاى شخصى و مطابق با شرايط سلامت فـرد ماند

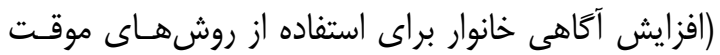
ولى طولانى اثر ييشخيرى از باردارى در كسانى كه موقتاً 
1990-2008. Natl Vital Stat Rep 2012; 60(7): $1-21$.

9. Abbasi-Shavazi MJ, Morgan SP, HosseiniChavoshi M, and McDonald P. Family change and continuity in Iran: Birth control use before first pregnancy. J Marriage Fam 2009; 71: 1309-24. doi: 10.1111/j.1741-3737. 2009.00670.x

10. Statistical Center of Iran. Announcement of preliminary results of population and housing census. Available at: https://www.amar.org.ir. Undated in: 2017.

11. Hosseini H, Bagi B. Demand for using contraceptive methods among Kurdish women in city of Mahabad in 2012. J Kermanshah Univ Med Sci 2013; 17(3): 18190. [In Persian]

12. Alie MV. The Role of population and demographic policies in strength the internal construction of the power of the Islamic Republic of Iran. J Afaq Security 2015; 8(28): 107-33. [In Persian]

13. Lawshe $\mathrm{CH}$. A quantitative approach to control validity. Pers Psychol 1975; 28: 56375.

14. Bahrami N, Soleymani MA, Sharifnia S H, Masoudi R, Shayegan H, Mohammad Rezaee ZH. Women's sexual satisfaction in different methods of pregnancy. Iran $J$ Nurs 2012; 25(76): 55-63. [In Persian]

15. Rahnama P, Hidarnia A, Amin Shokravi F, Kazemnejad A, Ghazanfari Z, Montazeri A. Withdrawal users' experiences of and attitudes to contraceptive methods: A study from Eastern district of Tehran, Iran. BMC Public Health 2010; 10: 779. doi: 10.1186/ 1471-2458-10-779.

16. Abbasi Shavazi MJ, Khademzadeh A. Reasons for choosing withdrawal method among women at reproductive ages in Rasht. J Reprod Infertil 2004; 5(4): 323-29.

$$
\begin{aligned}
& \text { انجام اين يزوهش را فراهم نمودند تشكر مىنماييه. ايـن }
\end{aligned}
$$

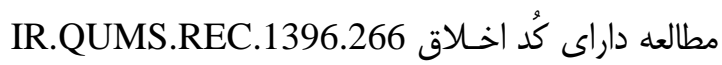

$$
\begin{aligned}
& \text { در دانشعاه علوم يزشكى قزوين مىباشد. }
\end{aligned}
$$

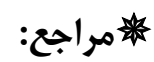

1. Kohan SH, Taheri S, Fadai S, Baghersad Z. Comperhensive Textbook of Maternal, Child and Reproductive health. 2nd ed. Esfahan, Iran: Kankash; 2013. 10-12.

2. Kohan S, Simbar M, Taleghani F. Empowerment in family planning as viewed by Iranian women: a qualitative study. J Biosoc Sci 2012; 44(2): 209-19. doi: 10.1017/ S0021932011000563.

3. Simbar M. Achievements of the family planning program in Iran. J Sch Public Health Inst Public Health Res 2010; 8(1): 81-92. [In Persian]

4. Nojah S, Latifi M. The effect of unwanted pregnancies on lactation in the first three-hour period after delivery. J Sabzevar Univ Med Sci 2001; 7(4): 37-42. [In Persian]

5. Jarahi L, Meysamie A. P, Fayaz Bakhsh A. Assessment of attitude and knowledge about intentional abortion in pre-married females. J Qom Univ Med Sci 2012; 6(1): 54-9. [In Persian]

6. International Medical Edu Services Study (IMES). Tehran: Health deputy, family health and population. Part 3: family planning indicators. 2006: 19.

7. Modabber MR, Pouresmaeil M, Soltani M. Effects of group discussion on knowledge, attitude and practice of women using natural family planning methods in Alborz City, Qazvin. J Health 2017 15; 8(2): 211-21. [In Persian]

8. Ventura SJ, Curtin SC, Abma JC, Henshow SK. Estimated pregnancy rates and rate pregnancy outcome for the United States, 
17. Simbar M, Ahmad M, Ahmadi G, Hamid AM. Quality of family planning services at health centers affiliated to Shahid Beheshti University of Medical Sciences. J Monitoring 2007; 6(2): 145-55. [In Persian]

18. Hosseini H, Bagi B. Reasons behind contraception discontinuation and switching among married women between 15 and 49 in Mahabad city (2012). J Kermanshah Univ Med Sci 2013; 17(9): 572-81. [In Persian]

19. Amiri M, Kasaeian A. Study of family planning service providers' knowledge about and attitude toward pregnancy prevention methods. Knowledge Health 2009; 4(1): 24-9. [In Persian]
20. Yalew SA, Zeleke BM, Teferra AS. Demand for long acting contraceptive methods and associated factors among family planning service users, Northwest Ethiopia: A health facility based cross sectional study. BMC Res Notes 2015; 8(1): 29. doi: 10. 1186/s13104-015-0974-6.

21. Baniaghil A, Khoddam H. Impact of group and individual education of family practice of women. J Gorgan Univ Med Sci 2005; 7(1): 43-6. [In Persian]

22. Haile A, Fantahun M. Demand for long acting and permanent contraceptive methods and associated factors among family planning service users, Batu town, Central Ethiopia. Ethiop Med J 2012; 50(1): 31-42. 